\title{
Performance and intestinal parameters of turkeys fed a diet with inulin and oligofructose*
}

\author{
Z. Zduńczyk ${ }^{1,3}$, J. Jankowski² and J. Juśkiewicz ${ }^{1}$ \\ ${ }^{1}$ Institute of Animal Reproduction and Food Research, Polish Academy of Sciences \\ Tuwima10, 10-747 Olsztyn, Poland \\ ${ }^{2}$ University of Warmia and Mazury in Olsztyn, Department of Poultry Science \\ Oczapowskiego 5, 10-718 Olsztyn, Poland
}

\begin{abstract}
The study was carried out to determine the effects of two fructans, long chain inulin and short chain oligofructose, on performance and caecal fermentation in turkeys. Feeding turkeys for 8 weeks with diets containing $2 \%$ fructans had no effect on performance indices. Oligofructose significantly lowered ileal $\mathrm{pH}$ in comparison with inulin and the control group (5.23 vs 5.90 and 6.04). Both fructans increased the caecal ammonia concentration and lowered caecal $\mathrm{pH}$. Oligofructose increased the production of total short-chain fatty acids ( 400.8 vs 333.9 and $284.8 \mu \mathrm{mol} / \mathrm{kg} \mathrm{BW}$ ), especially butyrate ( $124.8 \mathrm{vs} 106.1$ and $68.3 \mu \mathrm{mol} / \mathrm{kg} \mathrm{BW})$, in the caeca in comparison with inulin and the control group. Compared with inulin, oligofructose, a fructan with a lower degree of polymerization, more intensively affected the caecal metabolism of turkeys.
\end{abstract}

KEY WORDS: inulin, oligofructose, performance, SCFA, caeca, turkeys

\section{INTRODUCTION}

The addition of a prebiotic to a poultry diet can effectively improve the health and performance of birds (Patterson and Burkholder, 2003). In the relatively short gastrointestinal tract of turkeys, short-chain oligofructose should be expected to produce better results than long-chain inulin (Yusrizal et al., 2002). In our earlier experiments, the dietary addition of $0.4 \%$ inulin or oligofructose had no significant effect on the body weight of turkeys and negligibly changed the SCFA concentration in the caecal digesta (Juśkiewicz et al., 2002). The aim of the present study was to compare the effects of a higher content $(2 \%)$ of inulin and oligofructose in a diet on the performance and intestinal parameters associated with bacterial fermentation in turkeys.

\footnotetext{
* Supported by the State Committee for Scientific Research, Grant No. 3P06Z02124

${ }^{3}$ Corresponding author: e-mail: zez@pan.olsztyn.pl
} 


\section{MATERIAL AND METHODS}

The experiment was conducted on 60 three-day-old BUT-9 male turkey poults randomly assigned to one of three dietary treatments. Three diets were prepared: the control diet was formulated to meet the nutrient requirements of turkeys (NRC, 1994), in experimental diets, $20 \mathrm{~g}$ maize was replaced by long chain (99\% purity, average DP $=25$ ), sugar-free inulin (Frutafit-Inulin Tex, SENSUS, Netherlands) or oligofructose (Raftilose P95, 95\% of oligofructose $\mathrm{DP}_{2}$ to $\mathrm{DP}_{7}$, ORAFTI, Belgium). Diets were provided ad libitum for 8 weeks. Feed intake and body weight were measured. At the end, ten birds representing the average body weight of each group were killed. The selected parts of the gastrointestinal tract were removed and weighed. The $\mathrm{pH}$ was measured with a microelectrode and a $\mathrm{pH} / \mathrm{ION}$ meter in ileal and caecal digesta and the ammonia content was determined according to the standard Conway method. The content of short-chain fatty acids (SCFA) was determined by gas chromatography (Shimadzu GC-14A with a glass column 2.5 $\mathrm{m} \times 2.6 \mathrm{~mm}$, containing $10 \% \mathrm{SP}-1200 / 1 \% \mathrm{H}_{3} \mathrm{PO}_{4}$ on $80 / 100$ Chromosorb W AW, column temperature $110^{\circ} \mathrm{C}$, detector FID temperature $180^{\circ} \mathrm{C}$, injector temperature $\left.195^{\circ} \mathrm{C}\right)$. The results were statistically evaluated using one-way ANOVA and Duncan's multiple range test. Differences were considered significant at $\mathrm{P} \leq 0.05$.

\section{RESULTS}

Diet intake, body weight and FCR index of turkeys were unaffected by both fructan treatments (Table 1). Dry matter content in the ileal digesta was similar in all dietary treatments. The $\mathrm{pH}$ of ileal digesta was lower in the oligofructose group.

Table 1. Performance and intestinal parameters of turkeys fed diets with inulin and oligofructose

\begin{tabular}{lcccc}
\hline & \multicolumn{3}{c}{ Dietary treatment } & Pooled \\
\cline { 2 - 4 } & control & inulin & oligofructose & SEM \\
\hline Feed intake 1-4 weeks, kg & 1.36 & 1.35 & 1.39 & 0.02 \\
Feed intake 5-8 weeks, kg & 5.24 & 5.11 & 5.17 & 0.09 \\
Body weight at 8 weeks, kg & 3.85 & 3.78 & 3.88 & 0.06 \\
FCR 1-4 weeks, kg/kg & 1.64 & 1.60 & 1.61 & 0.02 \\
FCR 5-8 weeks, kg/kg & 1.77 & 1.78 & 1.75 & 0.03 \\
Dry matter of ileal digesta & 15.21 & 15.15 & 14.20 & 0.26 \\
pH of ileal digesta & $6.04^{\mathrm{a}}$ & $5.90^{\mathrm{a}}$ & $5.23^{\mathrm{b}}$ & 0.12 \\
Dry matter of caecal digesta, \% & 16.56 & 17.69 & 17.39 & 0.40 \\
pH of caecal digesta & $5.82^{\mathrm{a}}$ & $5.40^{\mathrm{b}}$ & $5.48^{\mathrm{b}}$ & 0.09 \\
Ammonia, mg/g caecal digesta & $0.60^{\mathrm{b}}$ & $0.61^{\mathrm{b}}$ & $0.87^{\mathrm{a}}$ & 0.04 \\
Caecal contents, g/kg BW & $3.59^{\mathrm{b}}$ & $4.33^{\mathrm{ab}}$ & $4.73^{\mathrm{a}}$ & 0.20 \\
Colon digesta, g/kg BW & $1.66^{\mathrm{b}}$ & $2.18^{\mathrm{ab}}$ & $3.01^{\mathrm{a}}$ & 0.13 \\
\hline a,b,c means within rows with no common superscript are $^{\mathrm{a}}$ different at $\mathrm{P} \leq 0.05$ &
\end{tabular}

$\overline{a, b, c}$ means within rows with no common superscript are different at $\mathrm{P} \leq 0.05$ 
The DM content in caecal digesta was unaffected by dietary fructans. The $\mathrm{pH}$ value of caecal digesta was significantly higher in the control group than in the experimental groups. A significantly higher concentration of ammonia in the caecal digesta was found in oligofructose group. The weight of caecal and colonic digesta was significantly higher in the oligofructose group than in the control group. The oligofructose treatment was associated with significantly higher total SCFA, butyrate and valerate concentrations (Table 2). As far as the $\mathrm{C}_{2}: \mathrm{C}_{3}: \mathrm{C}_{4}$ profile is concerned, both fructan-supplementations decreased the proportion of $\mathrm{C}_{2}$ and that of $\mathrm{C}_{4}$, compared with the control birds. The lowest values of total SCFA as well as of the acetate and butyrate pools were found in the control turkeys, while the smallest propionate pool, the inulin group. The highest values of the total SCFA pool and individual acids were observed in the group fed the oligofructose-supplemented diet.

Table 2. Concentration ( $\mu \mathrm{mol} / \mathrm{g}$ fresh digesta) and pool ( $\mu \mathrm{mol} / \mathrm{kg} \mathrm{BW})$ of SCFA

\begin{tabular}{lcccc}
\hline & \multicolumn{3}{c}{ Dietary treatment } & Pooled \\
\cline { 2 - 4 } & control & inulin & oligofructose & SEM \\
\hline Total SCFA concentration & $72.1^{\mathrm{b}}$ & $76.1^{\mathrm{ab}}$ & $98.2^{\mathrm{a}}$ & 4.80 \\
acetate & 48.0 & 45.1 & 57.3 & 2.82 \\
propionate & 4.01 & 2.64 & 3.72 & 0.34 \\
iso-butyrate & 1.11 & 0.68 & 1.07 & 0.09 \\
butyrate & $17.5^{\mathrm{b}}$ & $24.0^{\mathrm{ab}}$ & $30.6^{\mathrm{a}}$ & 2.15 \\
iso-valerate & 1.06 & 0.71 & 1.37 & 0.14 \\
valerate & $1.58^{\mathrm{ab}}$ & $1.05^{\mathrm{b}}$ & $1.79^{\mathrm{a}}$ & 0.12 \\
$\mathrm{C}_{2}: \mathrm{C}_{3}$ : C $_{4}$ profile, $\%$ & $68^{\mathrm{a}}: 6: 24^{\mathrm{b}}$ & $61^{\mathrm{b}}: 6: 28^{\mathrm{a}}$ & $62^{\mathrm{b}}: 4: 29^{\mathrm{a}}$ & - \\
Total SCFA pool & $284.8^{\mathrm{b}}$ & $333.9^{\mathrm{b}}$ & $400.9^{\mathrm{a}}$ & 22.8 \\
acetate pool & 189.8 & 197.8 & 234.1 & 13.0 \\
propionate pool & 15.85 & 12.19 & 15.41 & 2.02 \\
iso-butyrate pool & 4.37 & 3.02 & 4.48 & 0.41 \\
butyrate pool & $68.27^{\mathrm{b}}$ & $106.1^{\mathrm{ab}}$ & $124.8^{\mathrm{a}}$ & 10.22 \\
iso-valerate pool & $3.89^{\mathrm{ab}}$ & $3.12^{\mathrm{b}}$ & $6.48^{\mathrm{a}}$ & 0.64 \\
valerate pool & 6.27 & 4.60 & 7.30 & 0.53 \\
\hline
\end{tabular}

a,b,c means within rows with no common superscripts are different at $\mathrm{P} \leq 0.05$

\section{DISCUSSION}

Feeding turkeys for 8 weeks with both fructans ( $2 \%$ of a diet) did not influence the feed intake, body weight or feed conversion. Yusrizal et al. (2002) reported that a $1 \%$ addition of inulin and oligofructose increased the body weight and feed conversion ratio in broilers. In our study, dietary oligofructose was more effective than inulin in decreasing caecal $\mathrm{pH}$, but simultaneously it enhanced the ammonia concentration. The elevated level of caecal ammonia was a consequence of a 
higher activity of caecal microflora and it should not be considered as potentially detrimental. Similarly as in other experiments on poultry (Farnworth et al., 1996), the addition of fructan to diets did not affect the weight of the caecal wall, but increased the bulk of caecal digesta. A higher concentration and higher total production of SCFA also indicated a higher activity of bacteria in the caeca of turkeys fed a diet supplemented with oligofructose, compared with dietary inulin. This is consistent with the results reported by Yusrizal et al. (2002).

\section{CONCLUSIONS}

The obtained results point to higher fermentation efficiency in the caeca of turkeys fed a diet supplemented with short-chain oligofructose than with long-chain inulin. Consequently, compared with inulin, oligofructose may exert a stronger protective effect in the caeca of turkeys.

\section{REFERENCES}

Farnworth E.R., Modler H.W., Chambers J.R., 1996. Technical aspects related to the incorporation of bifidobacteria and bifidogenic factors in feed materials. Bull. IDF, 313, 52-58

Juśkiewicz J., Zduńczyk Z., Jankowski J., Król B., 2002. Caecal metabolism in young turkeys fed diets supplemented with oligosaccharides. Arch. Geflügelk. 66, 206-210

NRC, 1994. Nutrient Requirements of Poultry. $9^{\text {th }}$ revised Edition. National Academy Press, Washington

Patterson J.A., Burkholder K.M., 2003. Application of prebiotics and probiotics in poultry production. Poultry Sci. 82, 627-631

Yusrizal Y., Chen T.C., Van Loo J., 2002. Intestinal length and broiler weight as affected by inulin and oligofructose supplementation in diet. The $9^{\text {st }}$ Annual Meeting of the Poultry Science Association, Inc. University of Delaware, Abstr. 296

\section{STRESZCZENIE}

Efekty odchowu i parametry jelit ślepych indyków żywionych dietami z udziałem fruktanów o różnym stopniu polimeryzacji

Zbadano efekty odchowu i procesy fermentacyjne w jelitach ślepych indyków żywionych mieszankami z dodatkiem $2 \%$ różnych fruktanów: długo łańcuchowej inuliny i krótko łańcuchowej oligofruktozy. Dodatek fruktanów nie miał wpływu na wyniki 8-tygodniowego odchowu indyków. Oligofruktoza istotnie obniżała $\mathrm{pH}$ treści jelita cienkiego w porównaniu z inuliną i grupą kontrolną (5,23 vs 5,90 i 6,04). Fruktany zwiększały koncentrację amoniaku i obniżały pH w treści jelit ślepych. W porównaniu z grupą kontrolną, dodatek oligofruktozy zwiększył produkcję LKT w jelitach (z 284,8 do 400,9 $\mu \mathrm{mol} / \mathrm{kg} \mathrm{BW}$ ), szczególnie maślanów (z 68,3 do 124,8 $\mu \mathrm{mol} / \mathrm{kg} \mathrm{BW}$ ). W porównaniu z inuliną, oligofruktoza - fruktan o mniejszym stopniu polimeryzacji - intensywniej wpływał na metabolizm w jelitach ślepych. 